\title{
VARIATIONS IN THE NUMBER OF FORAMEN TRANSVERSARIUM: AN OSTEOLOGICAL STUDY
}

\author{
Amit Kumar Saxena1, Prachi Saffar Aneja², Naresh Kumar Sharma³, Harnam Singh Madan 4 \\ ${ }^{1}$ Associate Professor, Department of Anatomy, Faculty of Medicine and Health Sciences, SGT University, Gurgaon, Haryana. \\ ${ }^{2}$ Associate Professor, Department of Anatomy, Faculty of Medicine and Health sciences, SGT University, Gurgaon, Haryana. \\ ${ }^{3}$ Associate Professor, Department of Physiology, SHKM Medical College, Mewat, Nuh, Haryana. \\ ${ }^{4}$ Assistant Professor, Department of Orthopaedics, SHKM Medical College, Mewat, Nuh, Haryana.
}

\section{ABSTRACT}

\section{BACKGROUND}

Foramen transversarium is located on the transverse process of cervical vertebrae. These foramina are known to exhibit variations with regard to number, size, shape etc. Vertebral artery and vein passes through the FT of upper six cervical vertebrae.

\section{AIMS}

The aim of this study to observe the variations in number of foramen transversarium in typical cervical vertebrae.

\section{METHOD}

The study was done on 240 dry typical cervical vertebrae (C3-C6). Broken or damaged typical cervical vertebrae were excluded from the study.

\section{RESULTS}

In this study 20 cervical vertebrae (8.4\%) are having double foramen transversarium. Unilaterally and bilaterally the incidence of double foramen transversarium is $6.66 \%$ and $1.66 \%$ respectively.

\section{DISCUSSION AND CONCLUSION}

The variations of the foramen transversarium appears to more on lower cervical vertebrae. The knowledge of these variations are helpful for spinal surgeons and radiologist for evaluation of the patients.

\section{KEYWORDS}

Cervical Vertebrae, Foramen Transversarium, Vertebral Artery.

HOW TO CITE THIS ARTICLE: Saxena AK, Aneja PS, Sharma NK, et al. Variations in the number of foramen transversarium: an osteological study. J. Evolution Med. Dent. Sci. 2016;5(13):531-533, DOI: 10.14260/jemds/2016/122

\section{INTRODUCTION}

The cervical vertebrae are identified by the presence of Foramen Transversarium (FT) in the transverse processes. This foramen transmits the vertebral artery, vertebral vein and sympathetic fibers from the inferior cervical ganglion. $\mathrm{C} 7$ vertebra transmits only vertebral vein, sometimes this foramen is small or absent.

The transverse process of adult anatomy is morphologically a compound structure containing the foramen transversarium. It displays anterior and posterior roots or bars, which terminate laterally as anterior and posterior tubercles. The roots are connected lateral to the foramen by an intertubercular lamella of bone known as the costotransverse bar. ${ }^{1}$ The deformation and variations of this foramen may affect the anatomical course of vital vascular and neural structures and consequently cause pathological conditions. Double FT or "FT bipartite" is a rare condition and seldom reported in the literature.

Financial or Other, Competing Interest: None.

Submission 29-12-2015, Peer Review 24-01-2016,

Acceptance 30-01-2016, Published 12-02-2016.

Corresponding Author:

Dr. Amit Kumar Saxena,

Flat No. 4080, $1^{\text {st }}$ floor,

I. P. Ext-1, Near Achiever Shopping Mall, Sector 49,

Faridabad, Haryana.

E-mail: sonuamit33@gmail.com

DOI: $10.14260 /$ jemds/2016/122
The tortuosity of the vertebral artery may be a factor on the development of the variations of the FT. Embryological factors may also contribute to the development of these variations. The presence of the variation of FT may cause vertebrobasilar insufficiency as a result of neck movements. Variations in the number and size of the FT of cervical vertebrae may result in headache, migraine and fainting attacks due to compression of vertebral artery. ${ }^{2}$ the morphometry and anomalous variations of foramen transversarium are important to the spinal surgeon, neurosurgeon as well as the radiologist in determining the aetiology, side predilection, vascular variations in the cervical region. Clinically, this type of variations is important for the radiologist while doing computed tomographic and magnetic resonant imaging scan.

\section{MATERIALS AND METHODS}

This study was conducted on 240 dried human cervical vertebrae obtained from Department of Anatomy, SGT Medical College, Gurgaon, Haryana.

\section{Inclusion Criteria \\ Typical cervical vertebrae (C3-C6).}

\section{Exclusion Criteria}

Atlas and axis and C7 vertebrae and any defective or broken bones. 
Each cervical vertebra was examined macroscopically for the presence of the double foramen transversarium on one or both the side. Symmetry of foramen transversarium was also investigated. The duplication and symmetry of the FT were recorded and photographed.

\section{STATISTICS}

Vertebrae having double FT were recorded and photographed. The data was compiled and analyzed using Microsoft excel software.

\section{RESULTS}

Out of 240 dried cervical vertebrae, the double foramen transversarium was found in 20 cervical vertebrae.

Incidence of double FT was $8.4 \%$. Among them the unilateral duplication was found in 16 vertebrae, which was $6.66 \%$ and bilateral duplication was found only in four vertebrae which was $1.66 \%$. Thus unilateral duplication was more common than bilateral one. The accessory foramen were smaller than the regular foramen.

\section{DISCUSSION}

The foramen transversarium transmits vertebral artery and vein all cervical vertebrae except seventh. It can be assumed that variations in the course of vertebral vessels will cause variations in the foramen transversarium. An absence of FT could mean absence of vertebral artery or artery running along the transverse process.

In present study variations in the foramen transversarium were noted. The observations of the present study are supported by the observations found in earlier studies.

Taitz et al. ${ }^{3}$ (1978) reported 34 vertebrae, which were having accessory foramen transversarium.

Jarostow et al.4 (2003) reported accessory FT most frequent at the level of C- $6(45.6 \%)$ and rarest at C-3 (2.8)

Akram et al. ${ }^{5}$ reported accessory FT in lower cervical vertebrae, mostly in C-6 (70\%).

Das et al. ${ }^{6}$ (2005) reported 2 cases of accessory FT in 132 cervical vertebrae.

Sharma et al. ${ }^{7}$ (2010) reported accessory FT in 8\% of cervical vertebrae.

Kaya et al.8 (2011) reported accessory FT in $22.7 \%$ cervical vertebrae.

Murlimanju et al. ${ }^{9}$ (2011) reported accessory FT in $1.6 \%$ of cervical vertebrae.

Chandravadiya et al. ${ }^{10}(2013)$ reported accessory FT in $4.76 \%$ of cervical vertebrae.

Rathnakar et al. ${ }^{11}$ (2013) reported accessory FT in 5.7\% of cervical vertebrae.

Chaudhari et al.12 (2013) reported accessory FT 23.15\% of cervical vertebrae.

Katikireddy and Shetty. ${ }^{13}$ (2014) reported accessory FT in $3 \%$ of cervical vertebrae.

Patra et al. ${ }^{14}$ reported accessory FT IN $22 \%$ of cervical vertebrae.
Mishra et al. ${ }^{15}$ reported accessory FT in $14.09 \%$ of cervical vertebrae.

The variations in the number of foramen transversarium can be helpful for neurosurgeon, specially posterior cervical surgery and radiologist in studying the CT and MRI scans.

Double foramen transversarium may be correlated with duplicate vertebral artery. The cases of bifid and duplicate origin and fenestration of vertebral artery have been reported.

\begin{tabular}{|c|c|c|c|c|}
\hline $\begin{array}{c}\text { No. of } \\
\text { cervical } \\
\text { verte-brae } \\
\text { examined }\end{array}$ & $\begin{array}{c}\text { Vertebrae } \\
\text { double } \\
\text { Foramen } \\
\text { trans- } \\
\text { versarium }\end{array}$ & $\begin{array}{c}\text { Vertebrae } \\
\text { with } \\
\text { bilateral } \\
\text { double } \\
\text { Trans- } \\
\text { versarium }\end{array}$ & Total & $\begin{array}{c}\text { In- } \\
\text { cidence } \\
\text { in (\%) }\end{array}$ \\
\hline 240 & 16 & 4 & 20 & 8.4 \\
\hline \multicolumn{4}{|c|}{ Table 1: Showing Incidence of Double Foramen in Typical } \\
Cervical Vertebrae in Present Study \\
\hline
\end{tabular}

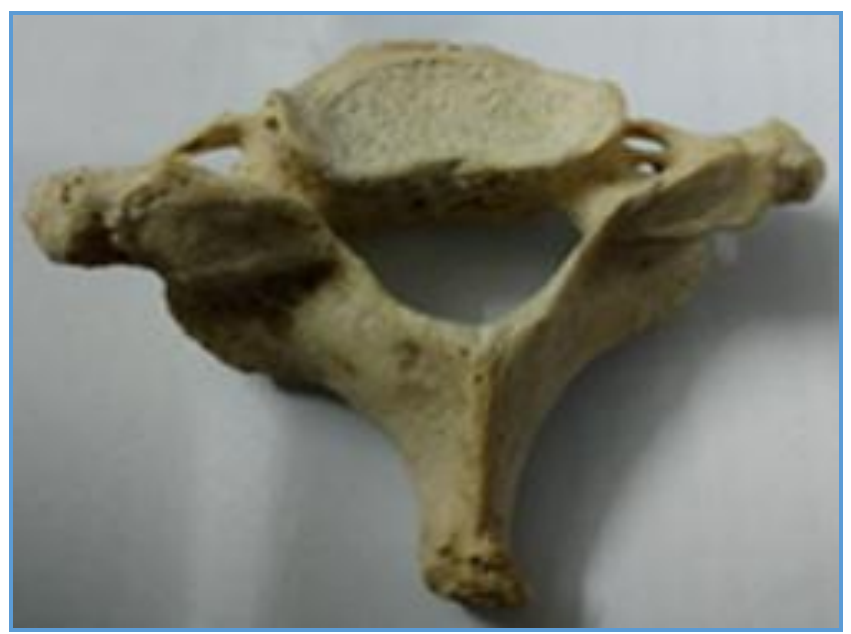

Fig. 1: cervical vertebrae with unilateral double foramen transversarium

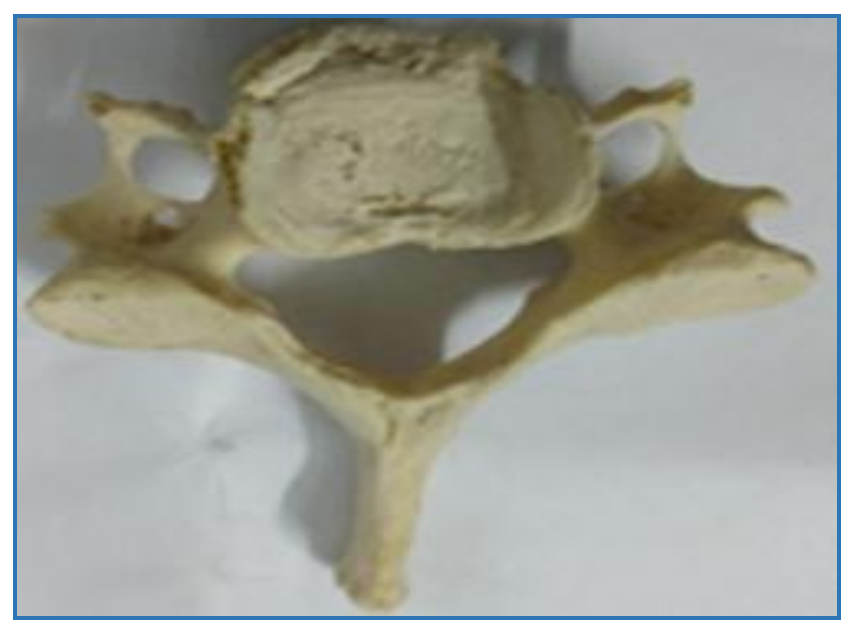

Fig. 2: Cervical vertebrae with bilateral double double foramen transversarium 


\begin{tabular}{|c|c|c|c|c|}
\hline Authors & $\begin{array}{l}\text { No. of } \\
\text { vertebrae } \\
\text { examined }\end{array}$ & $\begin{array}{c}\text { Incidence of double } \\
\text { foramen transversarium } \\
(\%)\end{array}$ & $\begin{array}{c}\text { Incidence of unilateral } \\
\text { foramen } \\
\text { transversarium }\end{array}$ & $\begin{array}{l}\text { Incidence of bilateral } \\
\text { double foramen } \\
\text { transversarium }\end{array}$ \\
\hline Taitz et al. & 480 & 7 & - & - \\
\hline Das et al. & 132 & 1.5 & & \\
\hline Sharma et al. & 200 & 8 & 3.5 & 4.5 \\
\hline Kaya et al. & 262 & 22.72 & 13.63 & 9.09 \\
\hline Murlimanju et al. & 363 & 1.6 & 1.4 & 0.3 \\
\hline Chandravidya et al. & 140 & 4.76 & 3.8 & 0.95 \\
\hline Rathnakar et al. & 140 & $5 . .7$ & 3.6 & 1.42 \\
\hline Chaudhary et al. & 133 & 23.15 & 14.73 & 8.42 \\
\hline Katikreddy et al. & 100 & 3 & 2 & 1 \\
\hline Patra et al. & 150 & 22 & 10.67 & 11.33 \\
\hline Mishra et al. & 220 & 14.09 & 4.54 & 9.54 \\
\hline Present study & 240 & 8.4 & 6.66 & 1.66 \\
\hline
\end{tabular}

\section{REFERENCES}

1. Grays Anatomy-The anatomical basis of clinical practice (39 th ed), Elsevier Churchill Livingstone, 743.

2. Caovilla HH, Gananca MM, Munhoz MS, et al. Syndrome cervical quadros clinicos otoneurologicos mais comuns. Atheneu, Sao Paulo, 2000. 3(11), 95-100.

3. Taitz C, Nathan H, Arensburg B. Anatomical observations of the foramina transversaria. J Neurol Neurosurg Psychiatr 1978;41(1):170-176.

4. Jarostaw Wysocki, Mariusz Bubrowski, Jerzy Reymond, et al. (2003). Anatomical variants of the cervical vertebrae and the first thoracic vertebra in man. Via Medica, 62:357-363.

5. Akram Abood Jaffar, Haydar Jawad Mobarak, Samir Adil Najm (2004). Morphology of the foramen transversarium a correlation with causative factors. AI-Kindy Col Med J 2(1):61-64.

6. Das Srijit, Suri Rajesh, Vijay K. Double foramen transversaria: an osteological study with clinical implications. Int Med J 2005; 12:311-313.

7. Sharma Archana, Singh Kuldeep, Gupta Vishnu, et al. Double foramen transversarium in cervical vertebra an osteological study. J Anat Soc India 2010; 59(2):229-231.

8. Chaudhari ML, Maheria PB, Bachuwar SP. Double foramen transversarium in cervical vertebra: morphology and clinical importance. Indian J Basic Appl Med Res 2013;2:1084-8.
9. Kaya Serdar, Yilmaz Nalan Damla, Pusat Serhat, et al. Double foramen transversarium variations in ancient byzantine cervical vertebrae: preliminary report of an anthropological study. Turkish neurosurgery, 2011;21(4):534-538.

10. Murlimanju BV, PrabhuLatha V, Shilpa K, et al. Accessory transverse foramina in the cervical spine: incidence, embryological basis, morphology and surgical importance. Turkish Neurosurgery. 2011;21(3):384-387.

11. Chandravadiya Laxmi, Patel Shailesh, Goda Jatin, et al. Double foramen transversarium in cervical vertebra: morphology and clinical importance. Int J Res Med 2013;2(1):103-105.

12. Rathnakar Pretty, Remya $\mathrm{K}$ and Swathi. Study of accessory foramen transversaria in cervical vertebrae. Nitte University Journal of Health Science. 2013;3(4):9799.

13. Katikireddi RS, Setty SN. A study of double foramen transversarium in dried cervical vertebra. Int J Health Sci Res 2014;4:59-61.

14. Patra A, Kaur H, Chhabra U, et al. 2015: Double foramen transversarium in dried cervical vertebrae: an osteological study. Indian journal of oral sciences 6(1):79.

15. Mishra GP, Bhatnagar S, Singh B, 2014: Anatomical variations in foramen transversarium of typical vertebrae and clinical significance. IJBR: 05(06):405-407. 